\title{
SIBINDE, André Raúl. Coexistência religiosa desafia as partes para o diálogo: o Cristianismo Católico e a Religião Tradicional Tsonga-Changana na construção de uma sociedade humanizada e justa no Sul de Moçambique. 2018. Dissertação (Mestrado) - Programa de Pós-graduação em Ciências da Religião, Pontifícia Universidade Católica de Minas Gerais (PUC Minas), Belo Horizonte.*
}

\section{Resumo}

Esta dissertação, apoiada na análise bibliográfica, descreve a Religião Tradicional Tsonga-Changana e o Cristianismo Católico no Sul de Moçambique, território acentuadamente marcado pela injustiça social contra a mulher e a criança. No passado, a afiliação religiosa servia para estimular e justificar guerras, homicídios e crueldades. Para erradicar essa atitude desumana no âmbito do fenômeno religioso, na segunda metade do século $\mathrm{XX}$, alguns autores cristãos passaram a ponderar sobre a cultura do diálogo inter-religioso. Neste contexto, em face da convivência inter-religiosa e das condições de injustiça social prevalecentes na sociedade Tsonga-Changana, esta pesquisa examina a possibilidade de o diálogo inter-religioso, no nível ético, entre as duas tradições religiosas - Igreja Católica e Religião Tradicional Tsonga-Changana - contribuir para o aprimoramento de suas identidades e atuações. A dissertação compõe-se, basicamente, de Introdução; (i)

\footnotetext{
* Orientador: Prof. Dr. Roberlei Panasiewicz. Defesa ocorrida em 07 de março de 2018. País de origem: Moçambique. E-mail do autor: andresibinde71@gmail.com.
} 
Descrição da experiência religiosa no Sul de Moçambique: Religião Tradicional Tsonga-Changana e Cristianismo Católico; (ii) Diálogo Inter-Religioso: uma necessidade; (iii) Tradições religiosas Tsonga-Changana e Cristã Católica ante a necessidade de humanizar a sociedade tsonga-changana; e Considerações finais.

Palavras-chave: Religião Tradicional Tsonga-Changana. Cristianismo Católico. Diálogo Inter-Religioso.

\begin{abstract}
This dissertation, using bibliographical analysis, presents a description of the Tsonga-Changana Traditional Religion and Catholic Christianity implanted in southern Mozambique; a territory particularly marked by social injustice against women and children. In the past, religious affiliation served to stimulate and justify wars, homicides, and cruelties. To eradicate this inhumane attitude within the religious phenomenon, in the second half of the twentieth century, some Christian authors pondered the culture of Interreligious Dialogue. In this context, in the face of interreligious coexistence and the conditions of social injustice prevailing in Tsonga-Changana society, this research examines the possibility of the interreligious dialogue between the Catholic Church and the Tsonga-Changana Traditional Religion - on the ethical contribution to the improvement of their identities and actions. To this purpose, this dissertation presents the following structure: description of the two traditions, analysis of the Interreligious Dialogue and an examination of the ethical level of the Interreligious Dialogue.
\end{abstract}

Keywords: Traditional Religion Tsonga-Changana. Catholic Christianity. Interreligious Dialogue. 